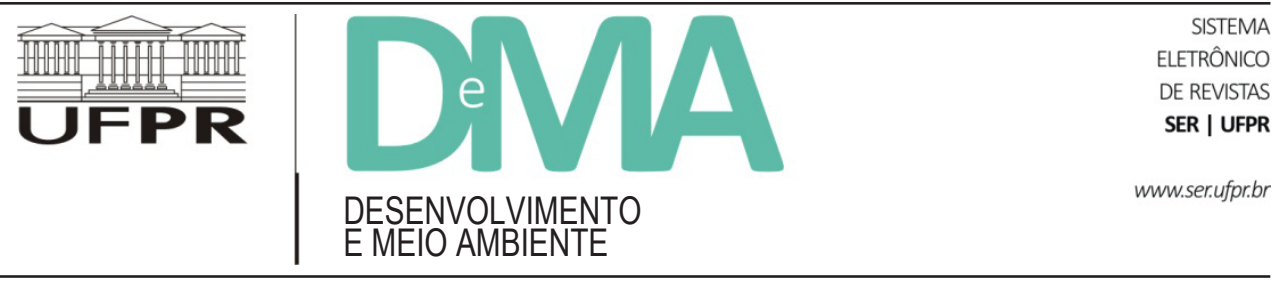

\title{
Ênfases jornalísticas na cobertura da COP 21 (Paris, 2015) nas versões norte-americana, brasileira e francesa do site The Huffington Post
}

\section{Journalistic Emphases in the COP 21 (2015) Coverage in the American, Brazilian and French Versions of The Huffington Post Site}

\author{
Myrian DEL VECCHIO DE LIMA ${ }^{1 *}$, Mônica Cristina FORT² ${ }^{2}$ Otávio Cezarini ÁVILA³ ${ }^{3}$ Augusta GERN, \\ Manoella Fortes FIEBIG ${ }^{1}$ \\ ${ }^{1}$ Universidade Federal do Paraná (UFPR), Curitiba, PR, Brasil. \\ ${ }^{2}$ Universidade Tuiuti do Paraná, Curitiba, PR, Brasil. \\ ${ }^{3}$ Instituto Federal de Educação, Ciência e Tecnologia do Paraná (IFPR), Curitiba, PR, Brasil. \\ *E-mail de contato: myriandel@gmail.com
}

Artigo recebido em 28 de outubro de 2016, versão final aceita em 14 de fevereiro de 2017.

RESUMO: O jornalismo é responsável por disseminar informações relevantes à sociedade e, com isso, pode, em determinados contextos, permitir reflexão e tomadas de decisão. No entanto, seu ethos discursivo acaba acentuando algumas ênfases. No jornalismo online, essa amplificação se acentua, pois é preciso despertar o interesse do internauta envolvido em um universo altamente fluido de conteúdo. De outra parte, a complexa questão das mudanças climáticas globais se tornou um tema midiático extremamente visibilizado; pesquisas na área apontam que a mídia evidencia ênfases alarmistas relacionadas a riscos e ameaças ambientais, pressupondo-se que isso pode levar à sensação de medo. Ao examinar a cobertura da Conferência das Nações Unidas sobre Mudança no Clima (COP21, Paris, 2015), perguntamos: quais ênfases se evidenciaram nas notícias sobre esse evento global? Como recorte, examinamos os títulos e lides das matérias publicadas na cobertura das edições brasileira, norte-americana e francesa do site The Huffington Post, analisando-os em suas "ênfases" e "enquadramentos". Ao final, questiona-se se, por meio dessa cobertura, o leitor pode ser levado à sensação de medo ou a uma sensibilização que estimule o enfrentamento dos riscos climáticos.

Palavras-chave: mudanças climáticas; jornalismo digital; cobertura jornalística; Ethos discursivo; COP21.

ABSTRACT: Journalism is responsible for disseminating relevant information to society, which may influence reflection and decision-making processes. However, its discursive ethos leads to giving more salience to certain aspects. In online journalism this amplification is accentuated as it needs to spark the interest of internet users who are involved in a highly fluid universe of content. The complex issue of global climate change has become a highly visible media theme but research suggests that the media often award emphasis to alarmist angles related to risks 
and threats, which can lead to feelings of fear. In examining the coverage of the United Nations Conference on Climate Change (COP21, Paris, 30/11 to 12/11/2015), we asked: which emphases were evidenced on the news about this global event? We analyzed the emphases and frames of headlines and leads of articles published in the Brazilian, American and French editions of the website The Huffington Post and whether such coverage might lead to feelings of fear or promote a form of awareness that enables responding to climatic risks.

Keywords: climate change; digital journalism; press coverage; rhetorical ethos; COP21.

\section{Introdução}

Este texto associa dois temas vinculados à contemporaneidade e aos chamados processos de globalização acelerada: o jornalismo digital online, ou jornalismo de Internet, campo ligado ao uso intenso das tecnologias de comunicação que emergiram a partir dos anos 1970; e as mudanças climáticas globais, alterações do clima que a maioria dos cientistas aponta estarem relacionadas à aceleração exponencial das atividades econômico-produtivas do ser humano, desde a Revolução Industrial, em especial aquelas ligadas à queima de combustíveis fósseis. Ao inserir uma questão ambiental (com definições científicas que apontam possíveis consequências desastrosas para o planeta), no âmbito do jornalismo, nos reunimos ao grupo de estudiosos (Bueno, 2007; Girardi \& Schwaab, 2008; Cox, 2009; etc.) que reflete sobre como a comunicação pode auxiliar na sensibilização e na politização da sociedade para enfrentar a crise socioambiental global, estabelecida desde meados do século passado.

Pode-se afirmar que, a partir dos anos 1990, em diversos países, como, por exemplo, na França (Comby, 2015), nos Estados Unidos (Giddens, 2010) $\mathrm{e}$, mesmo no Brasil, mais recentemente (Mendonça et al., 2013), houve uma intensa visibilidade midiática da questão climática, em especial pela via do jorna- lismo, que se constitui historicamente como espaço social de divulgação e esclarecimento da população sobre assuntos complexos, além de estimular o debate e a participação dos cidadãos em instâncias de ativismo. Mesmo levando-se em conta que os efeitos midiáticos não são automaticamente direcionados ou incorporados, as notícias sobre mudanças climáticas interferem nas formas de percepção sobre os seus riscos, sensibilizando as pessoas sobre o tema e, até mesmo, motivando-as para o enfrentamento do problema em âmbito local (Loose, 2016).

Já não há quase incertezas científicas com relação à causa antrópica das mudanças climáticas, como houve há alguns anos, prevalecendo as posições ligadas ao IPCC (Intergovernmental Pannel on Climate Change), ${ }^{1}$ entretanto, as incertezas permanecem quanto aos custos de ações e sobre quais seriam os melhores mecanismos e práticas para seu enfrentamento.

Os estudos voltados ao entendimento do papel e da interação social entre a mídia e os diversos atores sociais envolvidos na questão das mudanças climáticas e o público em geral têm crescido nos últimos 20 anos. As pesquisas têm analisado como "influências externas e internas às instituições jornalísticas incidem sobre o texto noticioso e que tipo de relação esse material simbólico tem sobre a experiência pública mais ampla acerca da questão"

\footnotetext{
${ }^{1}$ Criado em 1988, o IPCC agrega representantes de 194 países, milhares de cientistas que operam na condição de autores, colaboradores e revisores de estudos sobre o clima mundial. Tem como objetivo "fornecer aos governos do planeta, com uma base científica, clara visão do que está acontecendo com o mundo do clima". (IPCC, 2010. Disponível em: <http://www.ipcc.ir/>).
} 
(Cardoso, 2013, p. 23). Esse autor observou que a maioria dos trabalhos adota um recorte temporal bastante amplo e categorias analíticas mais genéricas para a análise do material noticioso. $\mathrm{O}$ autor aponta que os pesquisadores têm se preocupado em "saber quais as possibilidades de uma questão tão particular e complexa como o aquecimento global entrar na agenda pública de discussão propiciada pelos meios de comunicação de massa". Ele nomeia no panorama internacional diversos autores (Boykoff \& Boykoff, 2007; Carvalho \& Burgess, 2005; Anderson, 2009; McDonald, 2009) que buscam explicar como as questões das mudanças climáticas na mídia "enfrentam um risco premente de ou serem mal formuladas ou de nem mesmo ganhar as páginas dos jornais" (Cardoso, 2013, p. 19).

Sob um aspecto mais específico, há estudiosos que entendem que o enquadramento das notícias sobre mudanças climáticas, com abordagem em seus riscos à sociedade, seria uma boa estratégia para a sensibilização sobre o problema, permitindo às pessoas a tomada de decisões em seu cotidiano ou em suas práticas político-sociais. É o caso de Painter (2013), ao defender que o uso de uma linguagem com ênfase nos riscos no contexto de incertezas seria mais proveitoso para comunicar as alterações climáticas ao público do que salientar tragédias, embora isso varie de sujeito para sujeito e entre diferentes culturas. $\mathrm{O}$ autor argumenta que isso pode ser aplicável para formadores de opinião, embora seja necessário pesquisar mais para se conhecer os efeitos de tal uso sobre o público em geral. Hulme (2009) entende que o uso de uma linguagem que estimule o medo e o terror, enfatizando os desastres, conduz ao risco de se ignorar as precauções que se deve ter com previsões realizadas pela ciência.

Autores como Aguiar \& Schaun (2011) assinalam que as notícias sobre as catástrofes ecológicas passaram a ter amplo destaque na mídia, mas “esses discursos jornalísticos vinculam a crise do meio ambiente a uma heurística do medo, na qual o signo da negatividade esvazia a possibilidade da ação política" (Aguiar \& Schaun, 2011, s.p.). A constatação é baseada em pesquisa anterior dos autores, que levantou manchetes e chamadas sobre os problemas ambientais em dois jornais do Rio de Janeiro, O Globo e Jornal do Brasil, com 1.322 textos analisados entre 1992 e 2001 , verificando-se a premissa de que os riscos ecológicos se tornaram globais e de que os jornais marcam os valores contemporâneos sob a ótica da negatividade - a partir de uma pedagogia política centrada no medo coletivo. ${ }^{2}$

Outra pesquisa brasileira que compilou notícias sobre mudanças climáticas durante o segundo semestre de 2007, nos jornais Folha de S. Paulo e $O$ Globo, comprovou que esses dois jornais brasileiros seguiam tendências internacionais quando, em um primeiro momento, predominou o enfoque alarmista: "Uma gama de notícias sobre os fatos do amanhã foram publicadas. Bilhões de pessoas vão passar fome e ficar sem água, as geleiras da Groenlândia estão derretendo mais rápido que o previsto. A floresta amazônica vai virar savana." (Cardoso, 2013, p. 188).

Sob a ótica da opinião pública (aspecto que neste texto não é abordado, mas que apresenta rebatimentos sobre o medo em relação às mudanças climáticas), pesquisa do Pew Research Centre, ${ }^{3}$ reali-

\footnotetext{
${ }^{2}$ Algumas das manchetes encontradas por Aguiar \& Schaun (2011, p. 2): "Civilização desaparecerá em 20 anos"; "Desertificação já ameaça vida na Terra"; "Terra está em perigo, dizem 1575 cientistas"; "Caos no clima trará fome"; "Estudo lista os perigos do aquecimento global"; "Aumenta o risco de extinção global", entre outras.

${ }^{3}$ A pesquisa "Climate change seen as top global threat" está publicada no site <http://www.pewglobal.org/2015/07/14/climate-change-seen-as-top-global-threat/>. Acesso em: maio 2016.
} 
zada em agosto de 2015 com mais de 45 mil pessoas em 40 países, revelou que o maior temor de $46 \%$ dos entrevistados são as mudanças climáticas. Pediu-se a pessoas do mundo todo que classificassem alguns dos maiores problemas do nosso tempo: as opções para cada item eram "muito preocupado", "preocupado", "não muito preocupado" ou "nada preocupado". A opção "muito preocupado" foi prevalente entre os entrevistados na África e na América Latina.

Marc Augé (2013), ao falar das violências do mundo contemporâneo, incluindo entre elas "les violences de la nature", afirma que as violências sociais, políticas e tecnológicas se sobrepõem e se confundem, amplificando-se mutuamente, produzindo estresse e angústia, de forma que passamos a viver uma realidade marcada por um emaranhado de medos, reflexos do que se lê e se vê na mídia.

Diante desse contexto, ao acompanhar a cobertura da $21^{\text {a }}$ Conferência das Partes da Convenção-Quadro das Nações Unidas sobre as Mudanças Climáticas (COP 21), realizada em Paris, no período de 30 de novembro a 11 de dezembro de 2015, o mais importante evento público global sobre a questão, surgiu a pergunta: quais ênfases jornalísticas se evidenciaram nas notícias sobre esse evento?

Para buscar a resposta, foi preciso recortar o objeto em exame, a cobertura da COP21, diante da predefinição de outro objeto de pesquisa por um grupo internacional do qual fazemos parte. ${ }^{4}$ Assim, decidimos estudar a cobertura da COP21 realizada pelo site The Huffington Post, no original norte-americano e nas versões brasileira (HuffPost Brasil) e francesa (Le Huffington Post). Levamos em conta o entendimento de que o ethos discursivo jornalístico amplifica determinadas ênfases (Maingueneau, 2015) e que os recursos de edição inerentes ao texto jornalístico prezam por chamar a atenção aos dados mais relevantes e não raro sensacionais da notícia (Awad, 1995), selecionando leitores e valorizando certos aspectos. Consideramos ainda que, no jornalismo online, essa amplificação se acentua, pois é preciso despertar o interesse do internauta envolvido em um universo altamente fluido de conteúdos (Gern \& Del Vecchio de Lima, 2015).

Assim, como objetivo, optamos por examinar o conteúdo de alguns recursos de edição (com destaque para os títulos e lides) das publicações no período da COP21 dos três sites jornalísticos citados, de forma a poder observar e analisar algumas ênfases e possíveis indicadores das abordagens utilizadas que daí emergissem. Apesar das diferenças entre os recursos de edição (subtítulos, intertítulos, olhos, etc.) utilizados pelas três versões do jornal, produzimos uma planilha com itens que foram quantificados quando possível.

Definimos como material de análise qualitativa apenas as notícias: publicações assinadas por jornalistas e sem caráter opinativo evidenciado. Deixamos de lado a análise das fotos, por requerer abordagens específicas. A análise qualitativa das ênfases e enquadramentos evidenciados nos textos foi realizada de forma interpretativa, mediada pela linguagem e por conceitos prévios acerca do tema, com destaque para o papel não neutro do pesquisador.

\section{Jornalismo online: ampliação de ênfases e do sensacional}

Awad (1995) assevera que o contexto do jornalismo de massa não é apenas aquele da sociedade industrial hoje em acelerada transformação, mas

\footnotetext{
${ }^{4} \mathrm{O}$ grupo de pesquisa Journalisme à L'Heure du Numérique (JADN) tem estudado as caracterísitcas do The Huffintgon Post, em suas diversas versões internacionais.
} 
também é aquele de suas restrições intrínsecas, como o fato de se situar em uma empresa de mercado, de precisar atender às expectativas do público detectadas pelos setores de marketing, de suas ligações com as próprias fontes de notícias, das políticas de comunicação e de financiamento, etc.

Ao fazer essas observações sobre as restrições de um jornalismo de massa próprio do século XX, é preciso esclarecer que praticamente todas aquelas apontadas pela autora continuam válidas para um jornalismo de internet do século XXI, apesar da metamorfose da figura do receptor e de seu novo papel de interação ativa no processo, além da "reconfiguração midiática que desloca a ênfase da produção profissional para a circulação" (Rubleski, 2013, s.p.). Portanto, as observações apontadas se aplicam ao pure player ${ }^{5}$ aqui examinado, o The Huffington Post, mesmo diante de características específicas ${ }^{6}$ que também o enquadram como espaço de prática de um novo jornalismo, que confere a si próprio e a seus destinatários um status para a legitimação do seu saber. Seus discursos são, portanto, a priori, merecedores de crédito por parte da maioria dos segmentos do público.

Sob outra perspectiva, o enquadramento ( $\mathrm{fra}$ ming) se refere aos modos de os comunicadores apresentarem a informação, tornando-a acessível ao público. Robert Entman (1993) entende que os "quadros definem problemas, diagnosticam causas, fazem juízos morais e sugerem soluções" (citado por McQuail, 2013, p. 357). Há uma interpretação geral a itens nem sempre interligados, o que pode afastar a cobertura jornalística de uma objetividade presumida; e as fontes de informação também podem imprimir subjetividade. Consideram-se ainda os frames da audiência, ou seja, como as pessoas utilizam a informação e tiram conclusões/impressões sobre os temas discutidos na mídia. As sensações de medo ou ameaça, sob um espectro negativo, e a sensibilização para a tomada de atitudes, sob um espectro positivo, poderiam estar relacionadas a esse processo de enquadramento de notícias, entre outros processos socioculturais diários nos quais todos se inserem.

De outra parte, sabe-se que certos recursos de edição são expedientes técnicos elaborados e aplicados que ajudam a selecionar leitores e a valorizar questões centrais das notícias, ao chamar a atenção para os pontos mais relevantes e a partir dos filtros jornalísticos aplicados durante o circuito de produção da notícia. Na lógica da mídia (Altheide, 2013), notícias que provocam maior impacto, geralmente, recebem maior destaque, e os valores-notícia acabam sendo, em última instância, determinados pelo interesse do público. Há certos veículos de comunicação que não seguem esse nexo proposto por Altheide (2013). Mas, nos parece ser essa a lógica no caso dos clicks estabelecidos para "curtir" (likes), reproduzir ou comentar as publicações quando falamos de jornais exclusivamente online, como o The Huffington Post. São os clicks do público que determinam a permanência da notícia no site ou seu desdobramento nos próximos dias, assim como a publicação recorrente de temas preferidos pelo público.

\footnotetext{
${ }^{5}$ Empresa/produto informacional online, sem atividades comerciais offline. Caracteriza-se como uma mercadoria ofertada ao público por uma empresa informacional, sem custos, mas que garante "a reprodução de capital dos anunciantes, os grandes financiadores de fato do sistema". (Bolaño \& Vieira, 2012, p. 14).

${ }^{6}$ O The Huffington Post, lançado nos Estados Unidos, em maio de 2005 [...], nasceu no mesmo ano que o YouTube e reproduziu o sucesso daquela plataforma, transformando-se em uma mídia mainstream e tendo como principal missão: entregar uma informação "participativa", "autêntica" e "instântanea" (Roumanos \& Noblet, 2015, p. 68). Tradução livre do original em francês.
} 
As técnicas de redação e edição que buscam enfatizar aspectos de uma notícia parecem se acentuar ainda mais no sentido de se hipervisibilizarem no jornalismo digital. Nas reportagens multimídia, por exemplo, a contextualização pode ser feita por meio de hyperlinks, vídeos, áudios, etc. Além disso, "o formato multimídia tem a potencialidade de aproximar o leitor do tema, pelas ferramentas que estimulam a sensorialidade (olhar e audição), pela criação de empatia sonora e visual, remetendo de forma explícita a representações simbólicas estéticas." (Gern \& Del Vecchio de Lima, 2015, p. 15). ${ }^{7}$

Awad (1995) já perguntava acerca do jornalismo: a informação jornalística se reduz ao final a uma dose do sensacional que acompanha o verossímil? De fato, a própria seleção do que deve ou não ser notícia carrega em si o DNA do sensacionalismo, como aprendemos nos cursos de jornalismo ou na prática profissional. Mas, ao estudar o sensacionalismo, Awad (1995) entende que é preciso avançar o raciocínio. Para a autora, o sensacionalismo é um elemento que funciona como motor de um sistema de divulgação de eventos, sendo a notícia a formatação desses acontecimentos. O evento, ele mesmo, no caso deste texto, a COP21 de Paris, "é tomado previamente como um jogo, no âmbito de um conjunto de ingredientes" (Awad, 1995, p. 29). Ao se transformar em informação e ser formatado como notícia, o acontecimento/evento passa a ser representado por fragmentos de tudo o que foi coletado sobre ele por agências de notícias e correspondentes internacionais, além do que é comunicado pelas fontes, no mesmo jogo evenemencial.

No âmbito do jornalismo de Internet, as notícias circulam por diversas mídias e plataformas, são filtradas, recomendadas, "curtidas": como afirma Rubleski (2013, s.p.), "o simples ato de recomendar já significa uma mediação, a notícia, potencialmente, se afasta do enunciado no âmbito das redações, através de múltiplos e sucessivos (re)enquadramentos". O processo já configura a existência de um sensacionalismo difuso, que se estabelece nos processos de mediação durante o circuito de produção-consumo da notícia, condicionado pelas ligações intercambiáveis entre um jornal e as várias instâncias de seu contexto (Awad, 1995). Assim, o acontecimento termina por ser um enquadramento mental como notícia que ordena, releva e categoriza o fluxo dos fatos sociais no cotidiano.

Para Awad (1995), o conceito de sensacionalismo (ou sensacional) funciona como uma condição de segundo nível que dramatiza o evento (ruptura do cotidiano), transformando-o em espetáculo. Haveria algo mais apropriado para descrever a COP21 do que "um espetáculo global sobre o clima"? Apenas duas manchetes, pinçadas aleatoriamente do corpus da pesquisa do Le Huffington Post, ilustram esse aspecto, dramatizando os fatos do evento: "Arnold Schwarzeneggern'en a 'rien à foutre'si vous $n$ 'êtes pas d'accord avec lui sur le climat" (A.S. não dá a mínima se você não está de acordo com ele sobre o clima; 8 dez 2015) ou "COP21: dernières heures de négociations et nuit blanche en perspective" (COP21: últimas horas de negociações e noite em claro em perspectiva; $9 \mathrm{dez} 2015$ ). Ou o tom dramático de um título como esse retirado do mesmo corpus: "Airpocalypse Now: en pleines négociations climatiques à la COP21, un smog toxique" (Arpocalipse Agora: em plena negociação sobre o clima, uma neblina tóxica; 2 dez 2015).

\footnotetext{
${ }^{7}$ Essas constatações vêm sendo observadas, empiricamente, pelo grupo de pesquisa internacional JADN (Journalisme à l'heure du numérique), do qual fazemos parte, que tem estudado, desde 2014, as diversas edições internacionais do jornal online The Huffington Post, sob diversos aspectos editoriais e gráficos.
} 
Observamos, nos exemplos, que o ethos discursivo jornalístico vai muito além de ampliar determinadas ênfases do acontecimento. É o que Maingueneau (1993) relacionou à noção de tom, referindo-se à fala e à escrita. Qualquer discurso escrito possui uma vocalidade específica. Dito de outra forma, agora pelo viés da técnica, a notícia jornalística amplia o que é sensacional por meio de recursos técnicos: a feitura do título e do subtítulo, a seleção e publicação de fotos e elaboração de legendas, a produção de olhos, a própria técnica do lide e sublide. Ao levar essas características para o campo do jornalismo online, pudemos constatar, durante dois anos de pesquisa com diferentes versões do The Huffingfton Post, que a utilização de recursos multimídia, como a cada vez maior inserção de fotos, vídeos, posts de mídias sociais e áudios, evidencia de tal maneira esses apelos enfáticos que eles parecem gritar no contexto da notícia, ou seja, pela via da técnica, já ocorre a aceleração do motor sensacionalista no âmbito do evento e da informação.

Acrescentem-se a esta breve revisão sobre a inserção implícita do sensacional no texto jornalístico as quatro categorias definidas por Awad (1995) como configuradoras desse elemento na notícia: 1) a ruptura da normalidade, base do sensacional, perturbando os sistemas racionalistas de um meio (p. 167); 2) o conflito, condição de existência da dinâmica social, com os antagonismos entre interesses, escolhas e valores dos grupos sociais e suas disputas pelo poder e consenso (p. 169); 3 ) a violência sensacional, parte integrante da cultura do medo, característica da modernidade, da qual resulta uma apologia da segurança (p. 170); 4) a morte, que aparece como fato sensacional no espaço midiático, por constituir a negação que dela se faz na sociedade contemporânea (p. 174).

Ressaltados esses pontos, tenta-se compreender como os conceitos de risco e ameaça no âmbito climático, ao serem enquadrados e enfatizados pelo jornalismo, podem levar à sensação de medo ou aumentar a sensibilização e motivação para o seu enfrentamento.

\section{3. Ênfases sobre riscos e medos na cobertura sobre as mudanças climáticas}

Ao nos deter nos termos risco, catástrofe, ameaça, perigo, expressões que podem remeter à sensação de medo, utilizados no âmbito das notícias sobre mudanças climáticas, devemos também entender esses termos como definições científicas, uma vez que foi do campo da ciência que eles foram tomados. Autores da Geografia (Veyret, 2007), da Governança de Riscos (Giddens, 2010) e de outras áreas desenvolveram conceitos para definir situações de ameaça ou risco à integridade física, econômica ou psicossocial do ser humano, bem como ao meio ambiente.

Em um contexto de construção de percepção social sobre a crise ambiental, na qual as mudanças climáticas aparecem com destaque, Veyret (2007) elabora sua definição social de risco, deixando já claro que ela se diferencia da definição de perigo e de catástrofe, mas está a elas profundamente relacionada. A autora define o risco, um objeto social, como percepção do perigo, da catástrofe possível, enfatizando que o risco existe em relação ao indivíduo, grupo social/profissional ou sociedade e é apreendido por meio de representações mentais. Nessa definição, é fundamental a compreensão de que o risco apenas existe quando percebido pelo indivíduo ou por uma população que poderia sofrer seus efeitos.

Para a autora, ao se estudar o risco, o que se estuda é "a percepção de uma potencialidade de crise, de acidente ou de catástrofe, o que não é, portanto, 
o acontecimento catastrófico propriamente dito" (Veyret, 2007, p. 12). Há uma separação do evento concreto (o acontecimento natural, tecnológico, social, econômico) - que corresponde ao inglês hazard (perigo) ou a um fato objetivo que provoca consequências sobre um indivíduo, um grupo, um território - do risco em si, a percepção sobre este perigo (Mendonça et al., 2013).

Mas, como essas noções científicas se refletem na cobertura sobre as mudanças climáticas? Nas duas últimas décadas, a questão tem se apresentado como um discurso ampliado, provocado tanto pela comunidade científica, por outras instâncias político-ideológicas (governos, ONGs, a própria ONU), e pelos grupos econômicos ligados à produção e venda de sistemas de energia. O eco desse discurso é reproduzido global e localmente pela mídia. Inicialmente científico, ao se transformar em discurso de divulgação, repercute no público em geral e em diversas instâncias sociais, políticas e econômicas, obrigando suas fontes iniciais (cientistas, técnicos e autoridades) a reelaborá-lo, para refutar possíveis falhas e distorções do discurso midiático ou para aprová-lo/reiterá-lo (Mendonça et al., 2013).

Ao consumir todos os dias os fatos globais e locais, reproduzidos por textos, falas e imagens, a sociedade percebe-se vulnerável aos riscos socioambientais. Silverstone (2005) já apontou como uma parte significativa da percepção social se constrói por meio da leitura e apropriação dos conteúdos e mensagens das mídias de massa e das novas mídias digitais. Isso explica, em parte, a crescente percepção social que estabelece uma conexão entre mudanças climáticas e desastres naturais (Mendonça et al., 2013).

Estas percepções se inserem na chamada sociedade de risco, expressão utilizada desde os anos 1980 por autores da teoria social como Anthony Giddens e Ulrich Beck, para denominar as contradições da modernidade reflexiva, já em um contexto de crise socioambiental, quando a sociedade mundial passa a enfrentar a necessidade de repensar a sua relação com a natureza. E se o risco é uma construção social que apenas existe para quem o percebe, como afirma Veyret (2007), para a sociedade atual, essa noção se tornou onipresente, devido ao aumento universal de sua percepção, provocada em boa medida pelas mudanças da comunicação, em especial pela intermediação da Internet. Assim, da apreensão da sociedade sobre o aumento da ocorrência de desastres surge a percepção de que somos também uma sociedade mais exposta aos riscos ambientais. E nos sentimos especialmente vulneráveis quando expostos à espetacularização que a mídia faz sobre as tragédias naturais, como enchentes, tsunamis, terremotos, ondas de frio e calor extremos, etc. Não são os eventos/desastres naturais que se intensificam para Mendonça et al. (2013, p. 98), "mas a percepção sobre sua ocorrência em um mundo cada vez mais conectado pela informação, em que as intensas mediações midiáticas conduzem à criação sistemática de representações sociais".

De modo amplo, autores como Carvalho \& Burgess (2005), Anderson (2009) e Yun et al. (2012), ao estudarem a cobertura das mudanças climáticas, a partir da segunda metade dos anos 1980, apontam que, no início, essa cobertura era escassa e disseminada por especialistas no assunto. A questão da incerteza sobre a ocorrência do aquecimento global ganha fôlego nos anos 1990, bem como a discussão sobre suas causas serem antrópicas ou naturais. Cardoso (2013), baseado nos autores já citados, afirma que, aos poucos, o enquadramento científico perdeu espaço e deu lugar ao enfoque político das negociações internacionais, com predominância de autoridades políticas sobre as fontes científicas. Mas, desde os anos 2000, autores como Carvalho \& Burgess (2005) afirmam que, 
aos enfoques anteriores, veio somar-se um novo, o alarmista ou catastrófico, que expõe os impactos de eventos climáticos: "Este tipo de abordagem se adéqua melhor às práticas jornalísticas vigentes por proporcionar um tratamento mais dramatizador e passível de personalização - característica dos valores-notícia empregados nos textos jornalísticos." (Cardoso, 2013, p. 20).

Diante do exposto neste tópico, mesmo que exista a intencionalidade de sensibilizar as pessoas sobre as questões climáticas, pode-se perguntar, ao se verificar a forma como isso vem sendo realizado pela mídia, se o público não se sente ameaçado e com medo.

\section{Recortes da cobertura da COP21 no The Huffington Post}

O corpus empírico deste trabalho abrange as notícias que compõem a cobertura da COP21 em três sites do The Huffington Post (HP): a própria matriz norte-americana (www.thehuffingtonpost. com) e as versões francesa (www.lehuffingtonpost. fr) e brasileira (www.brasilpost.com.br). Explica-se: a versão original é um empreendimento jornalístico bem-sucedido que se multiplicou por mais 15 países (2016), com uma redação global, mais de 50 mil blogueiros e quase 50 milhões de visitantes únicos mensais nos Estados Unidos; o Huffington Post representa o que é um site jornalístico sem ligações com uma mídia impressa, mas que agrega informações de diversas outras mídias, impressas ou não, utilizando variados recursos interativos e multimídia. O site também se pauta por meio da contagem de clicks (audiência) e pelo uso massivo de publicidade nativa. ${ }^{8}$

A coleta inicial dos textos relativos à cobertura da COP21 realizou-se durante os 12 dias do evento, quando os sites dos três países foram visitados duas vezes ao dia, para se observar e acompanhar sua atualização. A coleta foi feita em todas as seções dos sites, a fim de identificar em qual editoria o tema era tratado. Todas as publicações foram salvas na íntegra, em formato JPG, e organizadas conforme o dia da publicação, horário e gênero jornalístico (notícia ou artigo de opinião). Em um segundo momento, reduziu-se o corpus coletado, para efeito de análise, apenas às publicações que se caracterizavam como notícias: aquelas jornalísticas, nas quais não se sobrepusesse um viés majoritariamente opinativo, e assinadas por repórteres ou editores. Ao final, foram recolhidas um total de 96 notícias, sendo 26 dos EUA; 59 da França (país sede do evento); e 11 do Brasil.

Consideraram-se, em termos de análise, os seguintes recursos de edição: 1) Título;2) Editoria; 3) Subtítulo (gravata); 4) Lide (primeiro parágrafo); 5) Recursos multimídia: a) fotos b) postagens c) vídeos d) gráficos/infográficos e) áudio. Para a análise qualitativa, foram mantidas as ênfases e os enquadramentos que emergiram apenas dos títulos, subtítulos e lide, bem como apenas as notícias sobre o evento em si; eventos paralelos no âmbito da COP21 e notícias sobre o tema mudanças climáticas exteriores ao evento em pauta.

O primeiro tipo de análise, que se deu a partir das ênfases encontradas, está ligado às evidências que emergem nos recursos de edição acima citados; trata-se do que é realçado retoricamente nesses

\footnotetext{
${ }^{8}$ Propaganda ou publicidade nativa é um conteúdo patrocinado por uma marca, mas produzido por jornalistas. A diferença é que esse conteúdo não é feito pela redação do meio onde ele será veiculado. Há uma equipe dedicada para a produção desse conteúdo para o cliente. (Paraizo \& Ferigato, 2014, s.p).
} 
fragmentos de discursos jornalísticos que, por si mesmos, já carregam um destaque visual. Buscou-se analisar os realces de conteúdo para se responder às seguintes questões: $\mathrm{O}$ que se enfatiza com relação ao evento/notícia? As ênfases são preponderantemente informativas (já que toda notícia se baseia em uma informação), ou já resvalam para o sensacional, por nela habitarem as retóricas do drama e do espetáculo?

O segundo tipo de análise ocorre a partir dos enquadramentos, ou seja, os modos pelos quais o texto jornalístico apresenta a informação, de maneira a torná-la acessível ao público, definindo problemas, causas, valores e soluções. Foram buscados, nos três recursos editoriais selecionados, daí emergindo os seguintes enquadramentos, definidos pela leitura analítica do texto: 1) de riscos ambientais: indicado por apontar riscos climáticos, mas também ameaças, alertas; 2) político: texto ligado a situações políticas, partidos, governos, movimentos sociais, autoridades e negociações, ideologias etc.; 3) econômico: textos ligados a situações econômicas, empresariais, de negócios, financeiras, de produção e consumo etc.; 4) didático-educativo: textos que primam pela explicação sobre dada situação, visando esclarecer o público de forma didática e estimular comportamentos e condutas ambientalmente corretas; 5) científico/ tecnológico: predomina a explicação científica sobre uma situação ou fato ou soluções tecnológicas; 6) de marketing/midiático: nos quais se evidenciam ações de marketing verde de governos ou ONGs ou enfatizam ações/apresentações midiáticas na área ambiental; 7) mobilizador para o enfrentamento dos riscos: primam por estimular ações mobilizadoras para o enfrentamento dos riscos; 8) de curiosidade: evidenciam aspectos peculiares e pitorescos, que chamam atenção do público.

\section{Análise das ênfases e enquadramentos em alguns recursos editoriais}

A análise do corpus inicia-se pela classificação de como cada publicação se relaciona com o evento COP21, uma vez que, para Awad (1995), o nível evenemencial ${ }^{9}$ estabelecido na notícia constitui a primeira representação de um fato, um enquadramento mental preestabelecido, inclusive pelo contrato de leitura que ocorre entre o jornal e seus destinatários. O evenemencial no sistema de informação se efetiva por meio do que ofato/evento apresenta em termos de extensão, de intensidade e representatividade simbólica.

A COP21 se enquadra no que podemos chamar de um megaevento global, realizada sob chancela da ONU, instância de governança mundial, com apoio de governos, empresas e instituições não governamentais internacionais. O evento é periódico e apresenta uma escalada de expectativas não cumpridas, parcialmente cumpridas ou cumpridas em termos de realização de acordos e recomendações sobre o clima, tornando-se um foro hegemônico em termos de repercussão das afirmativas do IPCC e dos cientistas a ele ligados. Simbolicamente, já possui um imaginário construído em torno de si, como espaço global onde se decide o futuro ambiental do planeta e o enfrentamento das consequências de uma crise climática.

Assim, localizamos as publicações por sua natureza com relação à COP21: Evento em si: cobertura de algo intrínseco à própria COP21, como um tema em discussão no âmbito do evento ou a

\footnotetext{
${ }^{9} \mathrm{O}$ termo de origem francesa não possui tradução literal para o português. Todavia, pode ser compreendido como o processo de construção de determinado acontecimento (Charaudeau, 2006).
} 
organização de ações a ele relativas, como alterações no trânsito local. 2) Evento paralelo: cobertura de outro evento paralelo à $\mathrm{COP}$, mas a ela tematicamente relacionado, como manifestações sobre o evento ou jantares com autoridades; 3) Tema do evento exterior a ele: publicações sobre mudanças climáticas, tema da COP, tratadas fora do âmbito do evento. A classificação realizou-se a partir da leitura dos títulos e lides. As 96 publicações ficaram assim distribuídas (Figura 1).

Não há surpresa quanto ao total de matérias sobre o evento em si no site francês, pois a França foi a sede da COP21. A marca francesa dada a essa COP fica evidenciada, principalmente, na cobertura posterior ao evento (que não faz parte do corpus quantitativo examinado, mas foi observada durante a leitura da totalidade da cobertura), onde se encontram matérias dedicadas à habilidade política dos franceses, liderados pelo chanceler Laurent Fabius, na costura final do acordo, quando se configura o evento pelo que foi vivido por este personagem como herói das negociações.

$\mathrm{Na}$ versão brasileira, constataram-se poucas publicações, já que nos dias 4, 5, 8, 9 e 11 não se encontrou material publicado. Em função disso, foram também observadas as matérias sobre a temática anteriores ao início da COP21, bem como na semana posterior ao seu encerramento. Na semana anterior, foram identificadas quatro publicações, duas sobre as expectativas em relação ao evento e duas sobre temas variados com alguma relação à COP. Já, após o término do evento, identificaram-se três matérias sobre o acordo firmado. Mesmo com a ampliação da coleta (que, no entanto, não teve matérias adicionadas ao corpus deste artigo para se manter a homogeneidade entre as três versões do si-

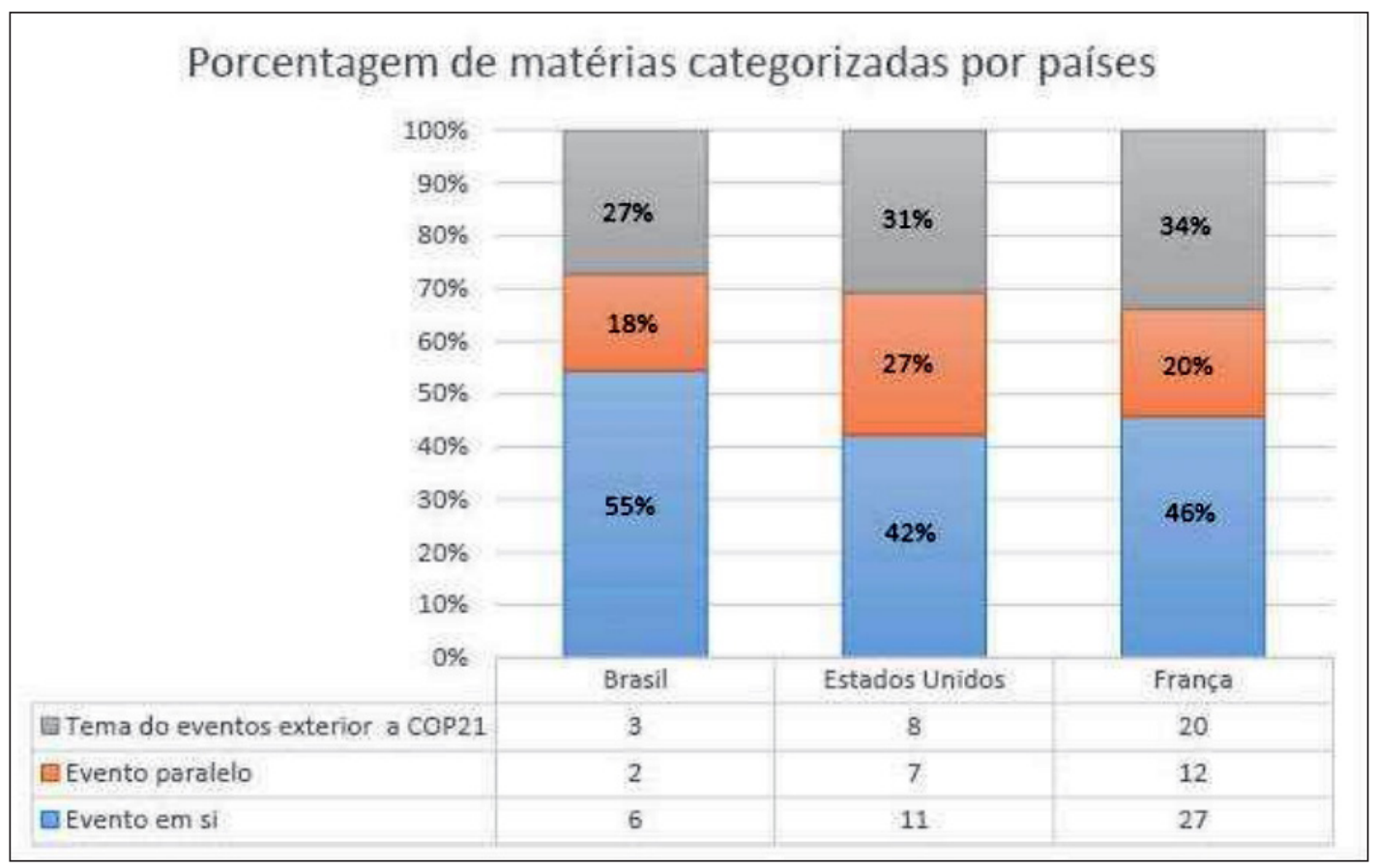

FIGURA 1 - Porcentagem de matérias categorizadas por países. 
te), identificamos a pouca relevância do assunto para o site brasileiro: durante os últimos quatro dias do evento, não houve uma única publicação - o retorno sobre as discussões e acordos ocorreu apenas no dia 12 de dezembro. A maioria das poucas publicações nacionais não foi produzida pela redação brasileira: ou veio de outros países ou, o mais recorrente, de outros veículos. Na época, a COP2 1 concorria, em termos de notícias ambientais no Brasil, com a tragédia do rompimento da barragem de resíduos de minérios em Mariana (Minas Gerais) e com a crise hídrica provocada pela má gestão do governo estadual, em São Paulo. Já a cobertura norte-americana é predominantemente política, com destaque para outro herói, produzido pela participação do presidente Barack Obama. Esse foco no político já se confirmara nas coberturas dos EUA sobre a temática, conforme revisões de Cardoso (2013).

No total de 96 publicações consideradas, 44 enfatizavam o evento em si (45,83\%); 21 publicações tinham por tema eventos paralelos $(21,87 \%) \mathrm{e}$ 31 publicações focaram o tema "mudanças climáticas e suas derivações", como aquecimento global ou energias renováveis (32,3\%). Aqui, há uma lógica jornalística de centralizar a cobertura no próprio megaevento e seu cortejo de celebridades políticas, científicas e do entretenimento ali presentes, que, por sua vez, geravam outros pequenos eventos durante todos os dias; a maioria das publicações enquadrou o que acontecia no núcleo decisor da conferência e seus personagens ou na sua organização como evento, que alterou a mobilidade dos parisienses; por outro lado, a cobertura é tradicional e pouco investiu nas dezenas de eventos paralelos que se realizaram na cidade em função da COP. A geração de apenas $21,87 \%$ de publicações sobre esses eventos paralelos mostra que é mais fácil permanecer na zona de conforto da cobertura oficial do evento principal. Mas, o conformismo também se deu no interior da cobertura do evento em si, que destacou as vozes oficiais dos acordos e promoveu sua espetacularização, como o registro da torre Eiffel coberta de vegetação, por exemplo. O percentual de 32,3\% de publicações sobre a temática das mudanças climáticas e suas derivações também revela a lógica do jornalismo ao repercutir o tema paralelo à conferência, a janela de oportunidade para falar de uma temática específica em um momento de sensibilização sobre ela.

Na sequência, são quantificados os recursos multimídia encontrados, definidos como "uma composição de várias mídias em um documento acessível a partir de uma mesma interface" (Azémard, 2013, p. 134), e que, neste trabalho, são entendidos como ênfases sensoriais e de conteúdo que acentuam o elemento sensacional no sistema evenemencial do jornalismo, representado pela circularidade entre o próprio evento, a informação em si e o sensacional, com sua carga de drama e espetáculo. Mas também acentuam as características de fluidez, redundâncias, hipertextualidade, hipercirculação e autorreflexividade do jornalismo digital. Saliente-se que toda essa carga enfática multimídia reforça a credibilidade da informação, ao trazer, paradoxalmente, a verossimilhança própria do jornalismo por meio de diversas formas de narrativa imagético-textual que, clicadas pelo leitor de internet, conduzem a outras possibilidades de leitura. Assim se distribuíram os recursos multimídia utilizados:

\section{a) Le Huffington Post (França)}

\begin{tabular}{|c|c|c|c|c|c|}
\hline EDITORIA & FOTO & POSTS & VÍDEO & GRÁFICO & ÁUDIO \\
\hline $\begin{array}{l}\text { COP21 (20) } \\
\text { Climat (13) } \\
\text { Environne- } \\
\text { ment (15) } \\
\text { Outras (11) }\end{array}$ & $\begin{array}{c}128 \\
\text { fotos } \\
\text { distri- } \\
\text { buídas } \\
\text { em } 36 \\
\text { matérias }\end{array}$ & $\begin{array}{c}117 \\
\text { posts } \\
\text { distri- } \\
\text { buídos } \\
\text { em } 25 \\
\text { matérias }\end{array}$ & $\begin{array}{c}31 \\
\text { vídeos } \\
\text { distri- } \\
\text { buídos } \\
\text { em } 23 \\
\text { matérias }\end{array}$ & $\begin{array}{l}38 \text { infográ- } \\
\text { ficos } \\
\text { em } 11 \\
\text { matérias }\end{array}$ & $\begin{array}{c}11 \\
\text { áudios } \\
\text { distri- } \\
\text { buídos } \\
\text { em } 3 \\
\text { matérias }\end{array}$ \\
\hline
\end{tabular}


Como pode ser observado, as editorias nas quais se verificou maior número de publicações foram a COP21 (20), Environnement (15) e Climat (13). As demais editorias publicaram apenas uma notícia em cada, são elas: Animaux, Architecture, Chine, Culture, Économie, Insolite, Gastronomie, Médias, Politique, Région e Science. A versão francesa é a que mais utiliza recursos multimídia, com destaque para a publicação de posts do Facebook ou Twitter, e muitas fotos, vídeos e infográficos. Comprovamos, em trabalho de campo, que a redação do Le Huffington Post, em Paris, possui nove profissionais dedicados à produção de vídeos. A edição francesa é a única que utiliza o recurso dos áudios na cobertura. Destaque para a diversidade das matérias sobre a COP ou mudanças climáticas a partir das 14 diferentes identificações (vinhetas de assunto).

\section{b) Huffington Post Brasil}

\begin{tabular}{|c|c|c|c|c|c|}
\hline EDITORIA & FOTO & POSTS & VÍDEO & GRÁFICO & ÁUDIO \\
\hline $\begin{array}{l}\text { Meio } \\
\text { Ambiente (11) }\end{array}$ & $\begin{array}{c}29 \text { fotos } \\
\text { em } 9 \\
\text { matérias }\end{array}$ & $\begin{array}{c}\text { Não } \\
\text { identi- } \\
\text { ficado }\end{array}$ & $\begin{array}{c}1 \text { vídeo } \\
\text { em } 1 \\
\text { matéria }\end{array}$ & $\begin{array}{l}1 \text { infográ- } \\
\text { fico em } 1 \\
\text { matéria }\end{array}$ & $\begin{array}{c}\text { Não } \\
\text { identi- } \\
\text { ficado }\end{array}$ \\
\hline
\end{tabular}

O Brasil tem a única versão do site que possui uma editoria de Meio Ambiente, com as 11 matérias nela publicadas. No período observado, o único recurso multimídia utilizado foi o das fotos, bem tradicional. Essa informação, aliada ao baixo número de publicações em relação aos demais países, permite inferir o pouco interesse da versão brasileira em noticiar o evento, o que pode ser justificado, talvez, pelos acontecimentos de repercussão nacional que ocorreram no período, como a tragédia do rompimento da barragem de Mariana e a crise hídrica em São Paulo, citando apenas os eventos da área ambiental. c) The Huffington Post (Estados Unidos)

\begin{tabular}{|l|c|c|c|c|c|}
\hline EDITORIA & FOTO & POSTS & VÍDEO & GRÁFICO & ÁUDIO \\
\hline Politics (7) & 45 fotos & 7 posts & 13 & 5 info- & Não \\
Impact (6) & em 15 & em 7 & vídeos & $\begin{array}{c}\text { gráficos } \\
\text { em 4 }\end{array}$ & $\begin{array}{c}\text { identi- } \\
\text { ficado }\end{array}$ \\
Science (5) & matérias & $\begin{array}{c}\text { publi- } \\
\text { cações }\end{array}$ & $\begin{array}{c}\text { matérias } \\
\text { matérias }\end{array}$ & \\
\hline
\end{tabular}

Das 26 matérias coletadas na versão americana, 25 levam consigo, logo abaixo do título, um subtítulo que o complementa. O veículo americano utiliza de maneira regular os recursos multimídias disponíveis. As publicações sobre a COP são identificadas por sete diferentes vinhetas (Science, Impact, Green, Live, Business, Politics e World), de acordo com a interdisciplinaridade do assunto em diferentes contextos.

\subsection{Análise qualitativa}

A análise qualitativa se baseou nos títulos e nos lides, e, no caso da versão norte-americana, nos subtítulos. Pela técnica jornalística, os títulos devem chamar a atenção do leitor para o assunto reportado. No texto noticioso factual, como os que compõem o corpus deste estudo, normalmente as informações do título são ampliadas no lide, sendo assim, foram consideradas também as informações do primeiro parágrafo dos textos para melhor compreensão dos títulos sempre que necessário. Os títulos noticiosos funcionam como anúncios para chamar a atenção do público, pois, suas poucas palavras, transmitidas com certo alarde, provocam nos leitores [de forma sutil e inconsciente] aspirações e desejos. Ou seja, a moral da história não deriva do não dito, mas do comunicado (Wainberg, 2015).

Para a análise qualitativa, partimos dos pressupostos já discutidos de Awad (1995), relacionados aos aspectos do sensacional e encontrados em textos de imprensa, e de Maingueneau (2015), quanto ao 
tom dos textos. Observamos que, durante um evento como a COP 21, há a oportunidade de se abordar questões que, embora circulem esporadicamente na mídia por serem de interesse público, estão naquela ocasião sendo intensamente discutidas por autoridades mundiais. Portanto, explora-se o enquadramento do tema em suas características de risco ambiental, políticas, sociais, econômicas, científicas, educativas, etc. No interior dos enquadramentos identificados, a análise buscou observar a ocorrência de ênfase no sensacional, com tom dramático, que pode amplificar ameaças ambientais, bem como a ênfase no espetacular, como apelo recorrente no âmbito noticioso. Como a análise é qualitativa, não se examinaram todas as notícias; também não há uma quantificação dos tipos de enquadramentos e ênfases, o que nos permitiu interpretá-los de forma breve e menos ortodoxa, como modo exploratório de se iniciar pesquisa mais ampla.

\section{- Primeiro dia: 30 de novembro}

Um exemplo de ênfase no sensacional, com retórica dramática, pode ser observado em reportagem logo no primeiro dia do evento na versão brasileira do Huffington Post: "Nossas maiores cidades ficarão submersas: Os horrores da mudança climática". Trata-se de título para noticiar um evento paralelo à COP21, a exibição, pelo jornal online "do novo filme do vencedor do Oscar, Charles Ferguson, intitulado Time to Choose" (Hora de Escolher), informa o lide. A frase que anuncia a reportagem é um depoimento que consta no filme, tanto que aparece entre aspas, mas é sensacional e ilustra uma catástrofe, algo que pode vir a acontecer. Dada a importância do título, saber que grandes cidades deixarão de existir, não importa em quanto tempo, é algo assustador, o que reforça o enquadramento midiático, mas também ambiental na ameaça provinda dos riscos climáticos. A versão francesa também apresentou chamada para o vídeo, mas com outro tom: "Regardez en exclusivité le nouveau film de Charles Ferguson sur le changement climatique" (Veja com exclusividade o novo filme de Charles Ferguson sobre mudanças climáticas). Ou seja, o enquadramento midiático não evidenciava a dramaticidade do filme, mas sim o evento promovido pelo jornal, caracterizando-se pelo tom informativo e de chamada para o leitor.

Chama a atenção a ênfase no sensacional com o qual outras notícias são apresentadas neste dia de abertura, aquele com maior número de reportagens sobre a COP21, publicadas nas três versões do jornal: quatro na brasileira; seis na norte-americana; 17 na francesa. Destacamos como exemplos: "These countries have the most to lose if Paris Climate Talks fail" (Estes países têm mais a perder se a Conferência de Paris sobre o Clima fracassar) - tom dramático; acompanhada do subtítulo: "Warming-fueled droughts and storms imperil populations, industries and even the existence of some countries" (Secas e tempestades provocadas pelo aquecimento global ameaçam populações, indústrias e até mesmo a existência de alguns países) - outra ameaça, outro perigo com ênfase sensacional e no enquadramento sobre riscos. Se algo não for feito, comunidades podem ser extintas, e as indústrias serão afetadas. Destaque-se mais uma notícia na versão brasileira: "Poluição sem precedentes: 12 fotos ALARMANTES mostram o problema na Índia e na China". Atenção para a palavra alarmantes escrita em letras maiúsculas. $\mathrm{O}$ texto grita como se fossem alertas de emergência, evidenciando a retórica do drama e o enquadramento no risco ambiental, agora realçado imageticamente.

Na versão francesa, neste primeiro dia, apesar da ênfase também sensacional em determinados momentos, as reportagens indicavam situações relacionadas à organização do evento. Houve destaque à comitiva do presidente norte-americano Barack 
Obama, em vídeo, inclusive, acentuando-se, pelo viés do espetáculo, que eram 20 carros que o acompanhavam na chegada a Paris, em um jornalismo típico de cobertura de celebridades.

Em outra reportagem, com enquadramento classificado como curiosidade, comentou-se o que os chefes de Estado iriam comer: "Le menu 9 étoiles qui sera servi aux chefs d'Etat à la COP21" (O menu nove estrelas que será servido aos chefes de Estado); convém comentar que, logo após, no lide da matéria, há informações de que será uma refeição sem ostentação, mas o fato de se associar no título a categorização do Guia Michelin ao preparo da comida insere o tom de espetáculo, embora também seja informativo e satisfaça a curiosidade do leitor que gosta de saber da vida das celebridades.

Para Maingueneau (1993), apresentar determinado discurso não quer dizer somente proferir um ou outro enunciado, mas sim adotar um certo tom, uma certa vocalidade que pode se manifestar em uma multiplicidade de tons. O modo de dizer está associado ao modo de ser. O autor salienta que o conceito de ethos está ligado à imagem formada com base na cena enunciativa.

\section{- Segundo dia: $1^{o}$. de dezembro}

No segundo dia do evento, em Paris, a cobertura está bastante aquecida. No entanto, a versão brasileira não traz nenhuma reportagem. Na França, seguindo uma lógica de entretenimento e curiosidade, o Huffington Post dá grande espaço a um photobomb: “À la COP21, le président des Comores fait le bonheur des internautes en gâchant une poignée de main historique" (Na COP21, presidente das Comores alegra internautas ao esconder um aperto de mão histórico). No lide, o texto informa que isso é o que se chama de estar no lugar errado na hora errada. Isso porque o presidente das Comores estava bem na frente das fotos no momento em que, após cinco anos, o presidente da Palestina, Mahmoud Abbas, e o primeiro-ministro de Israel, Benjamin Netanyahu, apertaram as mãos. Compreensível o destaque: os confrontos entre palestinos e israelenses são constantemente divulgados. Em um momento de trégua política, um ato de cordialidade entre as lideranças das nações em conflito não é registrado. A situação curiosa repercutiu quando internautas começaram a postar memes com a imagem do presidente das Comores sobrepondo fotos históricas.

Na versão norte-americana, duas notícias merecem destaque. A primeira, com enquadramento claramente político: “Obama: My successor has to take climate change seriously or they'll have no credibility" (Obama: 'Meu sucessor tem de levar a sério as mudanças climáticas ou não terá credibilidade'), com subtítulo: "Hint hint, Republicans" (Dicas, dicas, Republicanos); a segunda, com ênfase no alerta dramático, que pode levar à sensação de insegurança, ao utilizar a retórica do medo: "These will be the biggest losers if we don't properly address climate change" (Estes serão os maiores prejudicados se não tratarmos adequadamente as mudanças climáticas), com subtítulo "The world could see an increase in hunger, disease and job loss, among other devastating issues" (O mundo poderia ver aumento da fome, de doenças, da perda de emprego, entre outras questões devastadoras). Os títulos e subtítulos indicam riscos e ameaças. Embora a primeira notícia tenha caráter político, aponta uma condição na própria fala de Obama, que alerta seu sucessor(a), atribuindo a ele(ela) a responsabilidade pela segurança climática. No segundo título, observa-se a repetição de informação do dia anterior: os maiores perdedores caso nada seja feito. Essa questão de vencedores e perdedores é mais forte em determinadas culturas, o que fica claro ao se observar a ênfase dada na versão norte-americana. 


\section{- Terceiro dia: 2 de dezembro}

Nesse dia, a versão francesa apresentou oito reportagens, entre notícias e vídeos, relacionadas à COP21; a norte-americana, nenhuma; e a brasileira, uma. No Brasil, o título anuncia: “Oxfam: $10 \%$ dos mais ricos geram mais de $50 \%$ das emissões de $\mathrm{CO}_{2}$ ". Trata-se de uma informação de evento paralelo à conferência. Mostra o eterno conflito entre ricos e pobres, atribuindo-se a responsabilidade a quem tem poder aquisitivo pela eventual calamidade da maioria da população. $\mathrm{O}$ enquadramento é econômico, atividade humana que interfere na natureza e está na pauta das discussões do evento.

Na França, a cobertura é bem mais intensa. Uma das notícias, acompanhada de vídeo, apresenta tom sensacionalista, novamente explorando o tema das curiosidades, como muitas do período: "VIDÉO. Avec la pollution de l'air de Pékin, il a pu créer une brique" (Com a poluição do ar de Pequim, ele pode criar um tijolo). O vídeo mostra como o artista Nut Brother aspirou, durante cem dias, o ar poluído da cidade, e assim ele foi capaz de criar um tijolo com as partículas captadas pelo aparelho. Se a intenção do artista era protestar, ele conseguiu propagar sua voz por meio da imprensa. Há outros dois vídeos relacionados ao evento na edição do dia 2, mas aquele que reforça a ênfase sensacional e em tom dramático da cobertura é a reportagem já mencionada como exemplo neste artigo: "PHOTOS. Airpocalyspe Now: en pleines négociations climatiques à la COP21, un smog toxique recouvre Pékin" (Arpocalipse Agora: em plena negociação sobre o clima na COP21, uma neblina tóxica recobre Pequim). O trocadilho com o nome do filme Apocalipse Now, de Francis Ford Coppola, associa o conflito nas negociações sobre como as nações devem proceder para tentar salvar o planeta com o que se discute no filme de 1979: brutalidade exagerada, destruição da natureza e a questionada supremacia norte-americana na guerra do Vietnã. O fim do mundo (ou o fim do ar) é agora.

\section{- Quarto dia: 3 de dezembro}

Conforme os dias passam, a novidade com o evento diminui. No dia 3, a versão brasileira não apresenta nada da COP21; a versão francesa, que até então tem a cobertura mais completa, traz apenas três notícias relacionadas ao evento; já a versão norte-americana, nesse dia, enfatiza a realização da conferência, com cinco notícias e destaque para uma delas: "Climate Summit gets heat for huge carbon footprint, but it's not all bad" (Conferência do Clima chama a atenção para a enorme pegada de carbono, mas isso não é de todo ruim) como título, acompanhado do subtítulo: "Let's put the numbers in perspective" (Coloquemos os números em perspectiva). No lide, encontra-se a informação de que líderes de 195 nações discutem a redução da emissão de carbono, o aumento nos investimentos de energia renovável e a manutenção de uma economia mundial robusta. Trata-se de visão economicista que se reflete durante toda a cobertura, incluindo também a via política.

Outra reportagem, no dia 3, é exemplo desse enquadramento político: "U.S. should lead global fight against climate change, Americans say" (Estados Unidos devem liderar a luta global contra as mudanças climáticas, dizem americanos), com o subtítulo: "In a new poll, many say the next president should do more than Obama has" (Em nova pesquisa, muitos dizem que o próximo presidente deve fazer mais que Obama tem feito). Atribuir voz ao país em nome dos cidadãos americanos, indicando a maioria deles, seria mesmo adequado nesse título? Observa-se no lide que se trata de uma pesquisa realizada pelo HuffPost/YouGov junto aos leitores do jornal, mas, da forma como foi anunciada, com o enquadramento político eleitoral, desperta mais atenção do leitor. 
- Quinto dia: 4 de dezembro

No dia seguinte, a pesquisa volta a ser tema de reportagem na mesma versão do The HuffPost: "HUFFPOLLSTER: Americans sharply divided on climate change, but most want U.S. to lead" (Americanos nitidamente divididos quanto às mudanças climáticas, mas a maioria quer que os EUA liderem). Novamente aparece a questão da liderança política na luta contra as alterações no clima. Parece ser difícil a população norte-americana admitir outra eventual liderança mundial em qualquer área, mesmo no meio ambiente, área que deveria ser objeto de uma política de colaboração entre as nações, já que o ambiente natural ou culturalmente construído é um bem comum a todos e que, ao ser degradado, pode distribuir riscos e gerar problemas globais/ locais. Mas o título valoriza justamente a questão da liderança e supremacia norte-americana, enquadrando politicamente a notícia.

Já na versão francesa, destaque ao tom voltado ao espetáculo: "À la COP21, les stars aussi se mobilisent pour le climat" (Na COP21, "estrelas" também se mobilizam pelo clima), sobre a participação no evento de astros como Leonardo di Caprio, Robert Redford e Sean Penn. A presença de personalidades do cinema torna as discussões sobre o clima mais próximas dos cidadãos que acompanham os filmes que esses atores estrelam. A primeira frase do lide merece destaque pela associação ao assunto: "Tapis rouge pour le climat" (Tapete vermelho pelo clima), o famoso tapete da fama utilizado nas cerimônias do Oscar. Como afirma Maingueneau (2014, p. 77), “o leitor reconstrói a cenografia de um discurso com o auxílio de indícios diversificados". Assim, se até esse momento a conferência não tinha despertado a curiosidade de algum leitor, após essas celebridades serem apresentadas, há maiores chances de prestarem atenção ao assunto.
- Sexto dia e sétimo dia: 5 e 6 de dezembro

Não há notícias relacionadas à COP21 ou a mudanças climáticas na versão brasileira do Huff Post nos dias 3, 4 e 5 de dezembro, nem na norte-americana nos dias 5 e 6 . Na versão francesa, a cobertura prossegue no dia 5 (embora, no domingo, dia 6, não tenha sido publicado nada). Na edição do sábado, 5, as reportagens apresentam um tom mais sóbrio, menos alarmista e espetacular do que em edições anteriores, enfatizando o viés informativo. São exemplos: "Vers une économie à faible bilan carbone" (Rumo a uma economia de baixo carbono), com enquadramento econômico e "Les négociateurs de 195 pays venus pour la COP21 remettent une ébauche d'accord sur le climat" (Negociadores de 195 países vindos à COP2 1 enviam um projeto de acordo sobre o clima), com abordagem política.

A versão brasileira é a única com reportagens relativas à conferência no dia 6 . São três notícias, na editoria de Meio Ambiente, mas produzidas originalmente pelo site francês e todas elas já publicadas por ele: "As condições para o sucesso (ou o fracasso) da COP21"; "Garrafinha d'água, madeira reciclada, coleta seletiva: as pequenas iniciativas sustentáveis da COP21"; "Papa Francisco pede que autoridades combatam conjuntamente mudanças climáticas e pobreza". Os dois primeiros títulos, com ênfase informativa, anunciam notícias que são relatos do evento. Mas o primeiro, ao usar a expressão "sucesso ou fracasso", já apresenta a possibilidade de ser uma perda de tempo o encontro dos líderes mundiais, chamando a atenção, portanto, para os conflitos e as indefinições. No terceiro título, ao destacar o pedido do Papa às autoridades que participam da COP, há, indiretamente, uma espécie de convocação dos leitores a fazerem o mesmo, mobilizando-se. "O universo de sentido que o discurso libera impõe-se tanto pelo ethos quanto pela 'doutrina' [...] O texto não é para ser 
contemplado, ele é enunciação voltada para um coenunciador que é necessário mobilizar, para fazê-lo aderir 'fisicamente' a um certo universo de sentido." (Maingueneau, 2014, p. 73).

\section{- Oitavo dia: 7 de dezembro}

Nesta data, há notícias nas três versões. $\mathrm{Na}$ versão dos EUA, há um título com ênfase questionadora dramática, que apela para uma visão de tragédia futura: "Will the world reach an agreement to avert climate disaster this week?" (O mundo vai chegar a um acordo para evitar o desastre climático esta semana?); o subtítulo responde: "The next few days will decide the planet 's future" (Nos próximos dias, será decidido o futuro do planeta), já anunciando, de forma sensacional, que o final da conferência se aproxima. Dessa versão norte-americana, ainda destacamos uma contradição nas premissas de um enunciado: "We may get some good news about global carbon emissions this year" (Nós podemos ter boas notícias sobre a emissão global de carbono este ano), informa o título. Já o subtítulo desanima: “But don't celebrate too much. There's still a long way to go" (Mas não comemore muito. Ainda há um longo caminho a percorrer). Como possibilidade é diferente de probabilidade, não convém anunciar uma reportagem com algo que seja possível acontecer, principalmente se o subtítulo parece desmentir o título, pois, nesse caso, não há uma complementação, mais parece uma contradição.

O mesmo assunto foi destaque na versão francesa, mas com um título mais animador: "Surprise! Les émissions de CO2 ont sans doute baissé en 2015" (Surpresa! As emissões de CO2 devem baixar em 2015). Uma notícia com tom positivo. No entanto, a palavra "surpresa", seguida de ponto de exclamação, mostra como era algo improvável, até mesmo duvidoso. Nesse sentido, é possível recorrer novamente a Maingueneau (2014, p. 73), quando o autor afirma: "Paradoxo constitutivo: é por seu próprio enunciado que o fiador deve legitimar sua maneira de dizer". O fiador, o Le Huff Post, apresenta a notícia, dá o tom positivo, mas surpreende o leitor com uma novidade inesperada e inacreditável.

Outra reportagem, essa de evento paralelo, apresenta o título: "PHOTOS. Avaaz placarde dans Paris des affiches des 'plus grands criminales $d u$ climat' participant à COP21" (Avaaz cola em muros de Paris cartazes dos maiores criminosos ambientais participantes da COP21). Há um vídeo da ONG Avaaz com ativistas colando cartazes de sete climatosceptiques, autoridades céticas quanto às mudanças climáticas serem provocadas por ações do homem. A Avaaz considera essas pessoas criminosos ambientais infiltrados na conferência. Embora o título verbalize a ação da organização, o jornal compactua com essa voz; o tom é de denúncia, com um enquadramento mobilizador.

$\mathrm{Na}$ versão brasileira, a notícia de um tema relacionado ao evento, mas externo a ele, apresenta tom positivo: "Dez países africanos querem restaurar 100 milhões de hectares de florestas". Mas, a incerteza, como nos exemplos anteriores, está presente: querer, há uma intenção, mas não significa que será realmente implementada alguma ação efetiva. Assim, o título traz apenas uma expectativa. A versão brasileira não traz mais notícias relacionadas à COP2 1 até o dia 12 de dezembro, um dia após o encerramento oficial.

- Nono, décimo e décimo-primeiro dias: 8,9 e 10 de dezembro

A versão norte-americana, nos dias 8 e 10 de dezembro, apresenta pouco conteúdo relacionado à COP21 (em 9/12, inclusive, não publica nada). As notícias nesses dias estão principalmente relacionadas à necessidade do envolvimento de lideranças das cidades na luta pelo meio ambiente: "Paris $\mathrm{Cli}$ - 
mate Summit: cities lead fight against climate change" (Conferência de Paris sobre o Clima: lideranças municipais lutam contra mudanças climáticas). $\mathrm{O}$ assunto, um evento paralelo, é apresentado três vezes, uma com enfoque informativo, outra com enfoque mais didático e a terceira, mais dramático, o que salienta a arte de enquadrar um mesmo fato noticioso sob diversos aspectos e ênfases. Outra notícia, de 10 de dezembro, informa que há, no final da conferência, otimismo e realismo. O enfoque, nesse caso, é informativo.

Já a versão francesa, nos últimos dias da conferência, retoma o tom sensacional na maneira como anuncia as reportagens. São exemplos no dia 9: "On a résumé en 2 minutes les malheurs qui condamnent à devenir réfugié climatique" (Resumimos em dois minutos os infortúnios que nos condenam a tornarmos refugiados do clima), notícia acompanhada de um vídeo sobre a degradação do meio ambiente e suas consequências; "COP21: dernières heures de négociations et nuit blanche en perspective" (COP21: últimas horas de negociações e perspectiva de noite em claro); "Niger, Népal ou tribus péruviennes... les 'oubliés'des négociations à la COP21" (Nigéria, Nepal ou tribos peruanas... os esquecidos das negociações da COP21). E no dia 10 de dezembro: "Accord sur le climat à la COP21: un nouveau texte plux ambitieux, mais au prix de sacrifies" (Acordo sobre o clima na COP21: um novo texto mais ambicioso, mas a custa de sacrificios). Há dramaticidade nos enunciados dos títulos, e, mesmo quando o assunto é apenas um relato de fatos, como anunciar que as negociações chegam ao final, enfatiza-se que o prazo está acabando, então a expectativa é de trabalho extraordinário noite adentro.
- Décimo-segundo e último dia: 11 de dezembro

No último dia da conferência, anuncia-se que o texto final será divulgado somente no sábado, 12 de dezembro. "COP21: le projet d'accord final repoussé à samedi matin" (COP21: Projeto de acordo final adiado para sábado de manhã). Mas outros títulos chamam a atenção, como: "La nuit où ça $a$ vraiment chauffé à la COP21 (vue par un député belge écolo)" (A noite que realmente aqueceu a COP21 - vista por um deputado ecologista belga), a associação com o aquecimento global garante o viés do humor e reforça o tom sensacionalista. Na versão norte-americana, destacamos o título: "COP21 attendees reveal what scares them most about climate change" (Participantes da COP21 revelam o que mais temem quanto às mudanças climáticas). E o subtítulo: "As deal in Paris is expected this weekend, experts share their greatest fears about not reaching a strong, binding agreement" (Como a negociação em Paris é esperada para este final de semana, especialistas dividem seus maiores medos sobre não chegarem a um acordo forte, irrevogável). Há novamente um tom ameaçador no título, ressaltado pelo termo inglês scare, do verbo to scare = amedrontar, porque não há indicação do que são esses temores, mas sim de que há algo a se temer. Nesse caso, mesmo que o corpo da matéria vá esclarecer quais sejam os motivos dos temores, o título, enquanto recurso que usa poucas palavras com certo alarde (Wainberg, 2015), sintetiza o elemento sensacional da informação, generalizando-o, podendo levar à sensação de medo no leitor. Já o subtítulo refere-se ao medo dos especialistas em não fecharem um acordo forte sobre o tema: esse temor dos experts é transferido para os leitores, os coenunciadores do discurso, pois, como afirma Maingueneau (2015), o jornalismo amplifica questões geradas pela própria sociedade. 


\section{Considerações finais}

Questões relacionadas às alterações climáticas aparecem na mídia com relativa frequência desde os anos 1990. A cobertura jornalística voltada ao tema apresenta os mais diversos aspectos - visões céticas (negacionistas), olhares economicistas e tecnocráticos, textos que receitam boas práticas e exaltam ações empresariais verdes -, mas também apresenta, muitas vezes, conforme se acentuou neste texto, um tom alarmista, que pode inspirar a sensação do medo. Isso porque informações jornalísticas, pelo seu próprio ethos discursivo (Maingueneau, 1993), têm uma voz e, portanto, uma autoridade, que aproxima os leitores dos riscos climáticos, o que pode funcionar para determinados públicos de forma ameaçadora. Considerando-se os novos medos, inclusive os provocados pelas violências da natureza (Augé, 2013), estudar o discurso de jornalismo relativo às questões climáticas parece ser fundamental. Sendo assim, ao observar três versões do jornal online Huffington Post, o artigo partiu do pressuposto de que o evento realizado em Paris em 2015, a Conferência das Partes, reunindo autoridades de 195 países, era o momento ideal, uma vez que atrairia ainda mais a atenção da mídia para a temática.

Na cobertura realizada pelas três versões do Huffington Post, observaram-se diferenças editoriais. A versão brasileira abriu pouco espaço para matérias relacionadas ao evento, mas é possível compreender: a equipe do Huff Post Brasil é pequena, improvável que fossem designados repórteres para acompanhar o evento na França; além disso, como foi mencionado, as atenções da editoria de Meio Ambiente estavam voltadas à chamada tragédia de Mariana e à crise hídrica que afligia São Paulo na ocasião. A versão norte-americana iniciou a cobertura da COP 21 com enquadramento mais político e econômico, confirmando a revisão realizada por Cardoso (2013) sobre a politização e a abordagem econômica que marcam a cobertura do tema naquele país. Há títulos que deixam claro que, se é para se preocupar com questões de clima e adotar medidas para frear o aquecimento global, então o país deve assumir a liderança no processo, o que caracteriza uma visão típica do país também na temática ambiental. Na França, sede do evento, a cobertura foi mais intensa, com acompanhamento mais próximo, maior número de reportagens e maior diversidade nos enquadramentos, enfoques e ênfases adotadas.

Destaque-se no conjunto a cobertura evenemencial, ou seja, aquela em que o evento é a grande pauta da matéria por si mesmo, mas utilizando-se diferentes ênfases e enquadramentos, conforme aqui verificado, o que conduz a narrativa para diferentes tons: do dramático ao curioso, do alarmista ao espetacular, entre outros não analisados.

Observou-se que o tema das mudanças climáticas, mesmo relacionado a um evento mundial que discute o assunto, não possui uma editoria específica. Como dito, somente na versão brasileira há uma editoria de Meio Ambiente, onde foram publicadas as reportagens sobre a COP 21. Nas outras duas versões, as notícias foram marcadas com um selo do evento, no caso da versão francesa, ou ainda com as vinhetas Ambiente (Environnement), ou Clima (Climat) na primeira linha da matéria, ou de acordo com o aspecto correlato abordado, como gastronomia, arquitetura, ciência. Esse expediente também foi observado na versão norte-americana, com o maior número de reportagens publicadas com a rubrica de política, seguida de impacto e ciência. De maneira geral, observamos o tom sensacional e, às vezes, dramático na versão francesa, com muitos vídeos e fotos enfatizando temas que merecem análise específica em outro momento. 
Em relação ao uso de recursos multimídia e o fato de a análise tratar de um veículo online, identificou-se a pouca utilização de tais recursos nas versões norte-americana e brasileira, predominando matérias com apenas um recurso (foto, vídeo ou gráficos). A edição francesa explorou muito mais tais ferramentas, inclusive áudios e muitos posts no Twitter e no Facebook. Isso permite uma reflexão sobre a abordagem e relevância que se dedicam ao tema: o uso das potencialidades do ambiente online e a narrativa multimídia apontam novas perspectivas para a prática de reportagens sobre questões socioambientais, permitindo coberturas mais contextualizadas e abrangentes, abordagens sistêmicas (Gern \& Del Vecchio de Lima, 2015). Assim, na cobertura da COP 21, o uso dessas potencialidades se mostraria como ferramenta fundamental para contextualização. Além disso, esses recursos despertam a sensorialidade do leitor, aproximando-o de temas às vezes vistos como distantes e/ou complexos. Mas, simultaneamente, tais recursos aumentam a carga do sensacional embutido nos textos, ao mobilizar o olhar e a audição, ao levar à exploração de hyperlinks, ao utilizar infográficos explicativos e interativos. Nesse contexto, a edição francesa apresentou-se com uma cobertura mais atraente para o leitor, ao utilizar multiplicidade de recursos como vídeos, posts, áudios etc.

Apesar do tom sensacionalista de grande parte dos títulos das reportagens durante o evento, os enquadramentos, os mais diversos, pareceram ser positivos, relacionados a políticas para se evitar situações catastróficas. O tom dramático em diversas notícias - no qual está inserido o sensacional definido por Awad (1995) - pode conduzir ao medo, mas também servir para alertar que algo precisa ser feito para a defesa do indivíduo e do futuro da humanidade. Saliente-se o pouco uso de enquadramentos didático-pedagógicos mais explícitos ou mesmo de caráter mobilizador, nas três edições.
Finalmente, retoma-se Awad (1995) para lembrar que essa autora definiu quatro categorias que configuram o elemento sensacional na notícia jornalística, que agora relacionamos com a cobertura sobre a COP21: 1) a ruptura da normalidade, base do sensacional - nesse sentido, a emergência de alterações climáticas extremas se configura como uma ruptura ambiental, fazendo, portanto, parte do sensacional, tom/ênfase que caracterizou boa parte das notícias analisadas. 2) o conflito, que é condição de existência da dinâmica social. O palco de disputas e negociações políticas e econômicas em um evento como a COP21 retrata exemplarmente esse jogo, e é enfatizado na ênfase política dada pelas versões dos EUA e da França - o primeiro sempre buscando a ênfase na liderança internacional e a segunda, destacando a habilidade de negociação dos líderes franceses. 3) a violência sensacional - aqui, lembra-se das violências da natureza, apontadas por Augé (2013), agora amplificadas globalmente pela interferência do sistema produtivo e pela sua percepção em rede e também destacadas nas notícias examinadas. 4) a morte - no caso, as notícias sobre as mudanças climáticas representam a encenação da morte do planeta e de sua biodiversidade, no palco da COP21. Esse viés permite compreender como o jornalismo naturaliza o medo, em suas ênfases no espetáculo e no sensacional.

Resta uma questão final a ser privilegiada: em que medida uma cobertura com ênfase no sensacional, invocando um tom dramático, apontando riscos e gerando possíveis medos apresentaria percepções negativas ou positivas do público com relação à sensibilização para o enfrentamento das mudanças climáticas? Verificamos que esse é ainda um eixo de pesquisa pouco explorado, no qual pretendemos nos aprofundar, de forma a fazer com que o jornalismo contribua para o enfrentamento das questões climáticas de modo ativo e efetivo. 


\section{Agradecimentos}

À Comissão de Aperfeiçoamento de Pessoal do Nível Superior (Capes), que, por meio de qua- tro diferentes bolsas de estudo (uma de estágio de pesquisa de pós-doutorado na França e três bolsas de mestrado), contribuiu na elaboração deste artigo.

\section{Referências}

Aguiar, L.; Schaun, A. Heurística do medo: mídia e meio ambiente na sociedade de risco. Ação Midiática, 2, 1-15, 2011. Disponível em: <http://revistas.ufpr.br/acaomidiatica/ article/view/26423>.

Altheide, D. L. Media logic, social control, and fear. Communication Theory, 23, 223-238, 2013.

Anderson, A. Media, politics and climate change: towards a new research agenda. Sociology Compass, 3, 2, 166-182, 2009.

Augé, M. Les nouvelles peurs. Paris: Payot, 2013.

Awad, G. Du sensationnel: place de l'événementiel dans le journalisme de masse. Paris: Editions l'Harmattan, 1995.

Azémard, G. 100 notions pour le crossmédia. Paris: Les Éditions de l'Immatériel, 2013.

Bolaño, C.; Vieira, E. Economia política da internet: sites de redes sociais e luta de classes. In: Anais do XXXVI Congresso Brasileiro de Ciências da Comunicação. Manaus, 4-7 de set. 2012.

Boykoff, M. T.; Boykoff, J. M. Climate change and journalistic norms: a case-study of US mass-media coverage. Geoforum, 38(6), 1190-1204, 2007.

Bueno, W. da C. Comunicação, jornalismo e meio ambiente: teoria e pesquisa. São Paulo: Mojoara Editorial, 2007.

Cardoso, F. M. Mídia e mudanças climáticas no Brasil: entre demandas por crescimento econômico e desenvolvimento sustentável. Belo Horizonte, Dissertação (Mestrado em Comunicação Social) - UFMG, 2013.

Carvalho, A.; Burgess, J. Cultural circuits of climate change in UK broadsheet newspapers, 1985-2003. Risk Analysis, 25(6), 1457-1469, 2005.

Charaudeau, P. Discurso das mídias. São Paulo: Contexto, 2006.
Comby, J. B. La question climatique: genèse et dépolitisation d'un problème public. Paris: Édition Raison d'Agir, 2015.

Cox, R. Environmental communication and the public sphere. Thousand Oaks, California: Sage Publication, 2009.

Gern, A.; Del Vecchio de Lima, M. As racionalidades presentes na cobertura da Baía de Babitonga no jornal A Notícia. In: Anais do III Encontro Nacional de Pesquisadores em Jornalismo Ambiental. São Paulo, 20 out., 2015.

Giddens, A. A política da mudança climática. Rio de Janeiro: Zahar, 2010.

Girardi, I. M. T.; Schwaab, R. Jornalismo ambiental: as razões de um conceito. In: Girardi, I. M. T.; Schwaab, R. (Orgs.). Jornalismo ambiental: desafios e reflexões. Porto Alegre: Dom Quixote, 2008. p. 16-25.

Hulme, M. Why we disagree about climate change: understanding controversy, inaction and opportunity. New York: Cambridge University Press, 2009.

IPCC - Intergovernmental Pannel on Climate Change, 2010. Disponível em: <http://www.ipcc.ir/>. Acesso em: maio 2016.

Loose, E. B. Riscos climáticos no circuito da notícia local: percepção, comunicação e governança. Curitiba, Tese (Doutorado em Meio Ambiente e Desenvolvimento) UFPR, 2016.

Maingueneau, D. Novas tendências em análise do discurso. Campinas: Pontes, 1993.

Maingueneau, D. Ethos, cenografia, incorporação. In: Amossy, R. (Org.). Imagens de si no discurso: a construção do ethos. São Paulo: Contexto, 2014. p. 69-92.

Maingueneau, D. A propósito do ethos. In: Motta, A. R.; Salgado, Luciana (Orgs.) Ethos discursivo. São Paulo: Editora Contexto, 2015. 
McDonald, S. Changing climate, changing minds; applying the literature on media effects, public opinion, and the issue-attention cycle to increase public understanding of climate change. International Journal of Sustainable Development, 4, 45-63, 2009.

McQuail, D. Teorias da comunicação de massa. Porto Alegre: Penso, 2013.

Mendonça, F.; Deschamps, M.; Lima, M. D.V. A cidade e as mudanças globais: (intensificação?) riscos e vulnerabilidades na Região Metropolitana de Curitiba (RMC). In: Ojima, R.; Marandola Jr., E. (Orgs.). Mudanças climáticas e as cidades: novos e antigos debates na busca da sustentabilidade urbana. São Paulo: Blucher, 2013. p. 129-162.

Painter, J. Climate Change in the Media: Reporting Risk and Uncertainty. London: I. B. Tauris \& Co. Ltd, 2013.

Paraizo, D.; Ferigato, G. Publicidade nativa é opção para as marcas gerarem relevância com credibilidade. In: Portal Imprensa, 16 maio 2014. Disponível em: <http://portalimprensa.com.br/cdm/caderno+de+midia/65776/publicida- de+nativa + e + opcao+para + as + marcas + gerarem+relevancia + com+credibilidade $>$. Acesso em: maio 2016.

Roumanos, R.; Noblet, A. Le discours "positionnel" du Huffington Post: permanence et mobilité d'une narrations stratégique. Ação Midiática, 10, 55-80, 2015.

Rubleski, A. A crise de identidade do Jornalismo. Observatório da Imprensa, 749, 4 jun. 2013.

Silverstone, R. Por que estudar a mídia? São Paulo: Loyola, 2005 .

Veyret, Y. (Org.). Os riscos: o homem como agressor e vítima do meio ambiente. São Paulo: Contexto, 2007.

Wainberg, J. A. Os títulos, as emoções e a utopia. Intercom, Revista Brasileira de Ciências da Comunicação, 1, 191-211, 2015. doi: 10.1590/1809-5844201519

Yun, S.; Ku, D.; Han, J. A Comparative Analysis of South Korean Newspaper Coverage on Climate Change: Focusing on Conservative, Progressive, and Economic Newspapers. Development and Society, 41(2), 201-228, 2012. 